\title{
Marinobacterium coralli sp. nov., isolated from mucus of coral (Mussismilia hispida)
}

\author{
Luciane A. Chimetto, ${ }^{1,2,3}$ Ilse Cleenwerck, ${ }^{3}$ Marcelo Brocchi, ${ }^{1}$ \\ Anne Willems, ${ }^{4}$ Paul De Vos ${ }^{3,4}$ and Fabiano L. Thompson ${ }^{2}$
}

Correspondence

Fabiano L. Thompson

fabiano.thompson@biologia.ufrj.br

\author{
${ }^{1}$ Department of Genetics, Evolution and Bioagents, Institute of Biology, State University of \\ Campinas (UNICAMP), Brazil \\ ${ }^{2}$ Department of Genetics, Institute of Biology, Federal University of Rio de Janeiro (UFRJ), Brazil \\ ${ }^{3}$ BCCM/LMG Bacteria Collection, Ghent University, K. L. Ledeganckstraat 35, B-9000 Ghent, \\ Belgium \\ ${ }^{4}$ Laboratory of Microbiology, Faculty of Sciences, Ghent University, K. L. Ledeganckstraat 35, \\ B-9000 Ghent, Belgium
}

\begin{abstract}
A Gram-negative, aerobic bacterium, designated $\mathrm{R}-40509^{\top}$, was isolated from mucus of the reef builder coral (Mussismilia hispida) located in the São Sebastião Channel, São Paulo, Brazil. The strain was oxidase-positive and catalase-negative, and required $\mathrm{Na}^{+}$for growth. Its phylogenetic position was in the genus Marinobacterium and the closest related species were

Marinobacterium sediminicola, Marinobacterium maritimum and Marinobacterium stanieri; the isolate exhibited 16S rRNA gene sequence similarities of 97.5-98.0\% with the type strains of these species. 16S rRNA gene sequence similarities with other type strains of the genus Marinobacterium were below $96 \%$. DNA-DNA hybridizations between strain R-40509 ${ }^{\top}$ and the type strains of the phylogenetically closest species of the genus Marinobacterium revealed less than $70 \%$ DNA-DNA relatedness, supporting the novel species status of the strain. Phenotypic characterization revealed that the strain was able to grow at $15-42{ }^{\circ} \mathrm{C}$ and in medium containing up to $9 \% \mathrm{NaCl}$. The isolate could be differentiated from phenotypically related species by several features, including its ability to utilize $\mathrm{D}$-alanine, L-alanine, bromosuccinic acid, $\beta$-hydroxybutyric acid and $\alpha$-ketovaleric acid, but not acetate or L-arabinose. It produced acetoin (VogesProskauer), but did not have esterase lipase (C8) or catalase activities. It possessed $\mathrm{C}_{18: 1} \omega 7 \mathrm{c}$ (35\%), summed feature 3 (iso- $\mathrm{C}_{15: 0} 2-\mathrm{OH}$ and/or $\mathrm{C}_{16: 1} \omega 7 \mathrm{c} ; 25 \%$ ) and $\mathrm{C}_{16: 0}(22 \%)$ as major cellular fatty acids. The DNA G $+\mathrm{C}$ content was $58.5 \mathrm{~mol} \%$. The name Marinobacterium coralli sp. nov. is proposed to accommodate this novel isolate; the type strain is R- $40509^{\top}$ (=LMG $25435^{\top}=$ CAIM $1449^{\top}$ ).
\end{abstract}

Coral reefs are the most diverse marine biomes on Earth. They are constructed by a variety of invertebrates (e.g. corals, algae and sponges), serving as nurseries for marine life. These corals may secrete copious amounts of mucopolysaccharide material that contributes to the suspended organic matter in reefs (Wild et al., 2004). Coral mucus plays an important role as a carrier of energy and nutrients to a range of planktonic and benthic consumers (Ducklow \& Mitchell, 1979). Moreover, it represents an important resource for microbial growth in reef ecosystems (Brown \& Bythell, 2005). Corals harbour diverse microbial communities and are better seen as

The GenBank/EMBL/DDBJ accession number for the $16 \mathrm{~S}$ rRNA gene sequence of strain R- $40509^{\top}$ is GU183820.

A supplementary table is available with the online version of this paper. holobionts (i.e. coral host + zooxanthellae + microbes) (Brown \& Bythell, 2005; Rosenberg et al., 2007). In these holobionts, mutualistic interactions such as microbial nitrogen and carbon fixation are key processes that allow bioproductivity in the reefs. The key role of bacteria in coral health is well-documented by various examples of symbiotic and pathogenic relationships (Rosenberg et al., 2007). Bacteria living in coral mucus or tissue may act as a first line of defence for their holobiont hosts and protect them against diseases (Ritchie, 2006; Reshef et al., 2006; Shnit-Orland \& Kushmaro, 2009).

In the present study, a Gram-negative, aerobic bacterium $\left(\mathrm{R}-40509^{\mathrm{T}}\right)$, isolated from mucus of the coral Mussismilia hispida, one of the main reef builders of the South Atlantic Ocean, was investigated using a polyphasic taxonomic approach. Strain R-40509 ${ }^{\mathrm{T}}$ was isolated in the summer of 
2006 from apparently healthy coral located in the São Sebastião Channel at Preta beach $\left(23^{\circ} 49^{\prime} 10^{\prime \prime} \mathrm{S} 45^{\circ} 24^{\prime} 37^{\prime \prime}\right.$ W), São Paulo, Brazil. It was obtained on marine agar medium (MA; Difco) after incubation for $48 \mathrm{~h}$ at $28{ }^{\circ} \mathrm{C}$ as described previously by Chimetto et al. $(2008,2009)$. It was tentatively allocated to the genus Marinobacterium, which comprises 11 species, at the time of writing, from different sources and locations. Marinobacterium georgiense originated from marine pulp mill effluent enrichment cultures (González et al., 1997). Marinobacterium stanieri (Baumann et al., 1983; Satomi et al., 2002) and Marinobacterium jannaschii (Bowditch et al., 1984; Satomi et al., 2002) were isolated from coastal seawater, and Marinobacterium litorale and 'Marinobacterium marisflavi' (Kim et al., 2007, 2009a) were from seawater of the Yellow Sea. Marinobacterium halophilum (Chang et al., 2007) and Marinobacterium lutimaris (Kim et al., 2010) were isolated from tidal flats (Getbol), whereas Marinobacterium rhizophilum originated from roots of plants inhabiting a coastal tidal flat (Kim et al., 2008). Marinobacterium nitratireducens and Marinobacterium sediminicola were isolated from sea sediment (Huo et al., 2009), whereas Marinobacterium maritimum was isolated from Arctic marine sediment (Kim et al., 2009b).

Bacterial genomic DNA and 16S rRNA gene sequences were obtained as described previously (Thompson et al., 2001; Chimetto et al., 2008, 2009). Raw sequence data were transferred to the ChromasPro v.1.34 software (Technelysium, Tewantin, Australia), where consensus sequences were determined. Sequences were aligned using the Clustal W software (Chenna et al., 2003). Pairwise similarities were calculated with the software BioNumerics 4.5 (Applied Maths) using an open gap penalty of $100 \%$ and a unit gap penalty of $0 \%$. Similarity matrices and phylogenetic trees were reconstructed using the software MEGA4.0 (Tamura et al., 2007) and BioNumerics 4.5. Trees were drawn using the neighbour-joining (Saitou \& Nei, 1987), maximum-parsimony (Eck \& Dayhoff, 1966) and minimum evolution methods (Rzhetsky \& Nei, 1992). The robustness of the tree topologies was checked by 1000 bootstrap replications (Felsenstein, 1985). The gene sequence data obtained in this study are also available through the website TAXVIBRIO (http://www.taxvibrio. lncc.br/).

DNA-DNA hybridization experiments were performed using the microplate method described by Ezaki et al. (1989), with minor modifications (Willems et al., 2001). Hybridizations were performed at $46{ }^{\circ} \mathrm{C}$ in the presence of $50 \%$ formamide in four replicates. Reciprocal reactions were performed for every DNA pair in four replicates and their variation was within the limits of this method (Goris et al., 1998). DNA G $+\mathrm{C}$ contents were determined by HPLC as described previously (Mesbah et al., 1989). Analysis of fatty acid methyl esters was carried out as described by Huys et al. (1994). For fatty acid analysis, cells of the novel strain and the type strains of the closest known species (M. sediminicola, M. maritimum and M. stanieri) were grown on MA (Difco) for $24 \mathrm{~h}$ at $28{ }^{\circ} \mathrm{C}$ under aerobic conditions. Phenotypic characterization was performed using the API ZYM, API 20E and API 20NE kits (bioMérieux), and the Biolog GN2 microwell plates, according to the manufacturers' instructions, but with minor modifications, i.e. cell suspensions for inoculation of the API tests were prepared in a $3 \%(\mathrm{w} / \mathrm{v}) \mathrm{NaCl}$ solution and those for the Biolog GN2 microwell plates showed a turbidity (transmission) of $20 \%$. Cells for the suspensions were grown on Biolog medium for $24 \mathrm{~h}$ at $28{ }^{\circ} \mathrm{C}$ under aerobic conditions. Tests were read after $24-48 \mathrm{~h}$ of incubation at $28{ }^{\circ} \mathrm{C}$. Growth at different temperatures $\left(4-45{ }^{\circ} \mathrm{C}\right)$ and salt concentrations $(0-14 \% \mathrm{NaCl}$; determined at $28{ }^{\circ} \mathrm{C}$ ) was determined by incubation on TSA (Difco) for $72 \mathrm{~h}$. Catalase activity was determined by adding young cells to a drop of a $3 \% \mathrm{H}_{2} \mathrm{O}_{2}$ solution and observing whether $\mathrm{O}_{2}$ was produced. Oxidase activity was tested using $1 \% \quad N, N, N^{\prime}, N^{\prime}$-tetramethyl $p$-phenylenediamine (Kovacs, 1956).

Based on $16 \mathrm{~S}$ rRNA gene sequence analyses, the phylogenetic position of strain R- $40509^{\mathrm{T}}$ ( $16 \mathrm{~S}$ rRNA gene sequence of $1349 \mathrm{nt}$ ) was in the genus Marinobacterium and, more precisely, in a robust phylogenetic subcluster containing the species M. sediminicola, M. maritimum and M. stanieri (Fig. 1). The 16S rRNA gene sequence similarities between strain $\mathrm{R}-40509^{\mathrm{T}}$ and the type strains of these species were 98.0-97.5\%, whereas they were below 96\% with the type strains of other known species of the genus Marinobacterium.

DNA-DNA hybridization experiments were performed between strain R-40509 ${ }^{\mathrm{T}}$ and the type strains of the closest phylogenetic neighbours (i.e. M. sediminicola, M. maritimum and $M$. stanieri) (Table 1). The DNA-DNA relatedness values for $\mathrm{R}-40509^{\mathrm{T}}$ with these species were

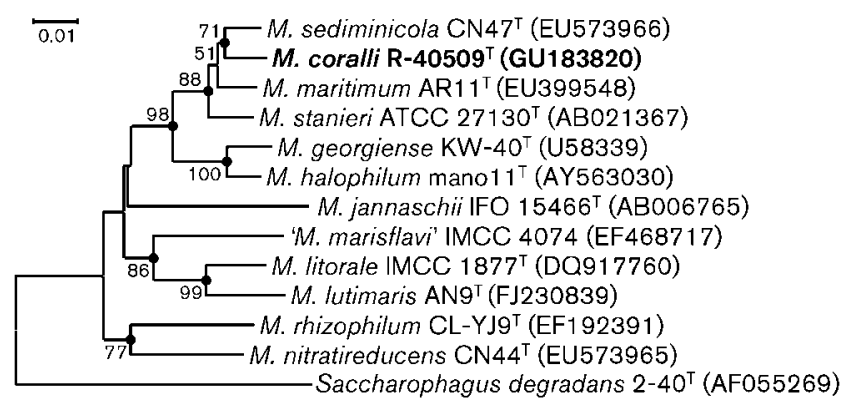

Fig. 1. Neighbour-joining tree showing the phylogenetic position of Marinobacterium coralli sp. nov. based on 16S rRNA gene sequences. Evolutionary distances were computed using the Kimura 2-parameter method (Kimura, 1980). All positions containing gaps and missing data were eliminated from the dataset (complete deletion option). Phylogenetic analyses were conducted using the MEGA4 software. Bootstrap values $(>50 \%)$ based on 1000 resamplings are shown. Solid circles indicate that bootstrap values $>60 \%$ were recovered in the maximum-parsimony and the minimum evolution trees. Saccharophagus degradans $2-40^{\top}$ was used as outgroup. Bar, $1 \%$ estimated sequence divergence. 
Table 1. DNA-DNA hybridization data, $16 \mathrm{~S}$ rRNA gene sequence similarities (\%) and DNA G+C contents of Marinobacterium coralli sp. nov. and related species of the genus Marinobacterium

\begin{tabular}{|c|c|c|c|c|c|c|}
\hline \multirow[t]{2}{*}{ Strain } & \multirow{2}{*}{$\begin{array}{c}\mathrm{G}+\mathrm{C} \text { content } \\
(\mathrm{mol} \%)\end{array}$} & \multirow{2}{*}{$\begin{array}{c}\text { 16S rRNA } \\
\text { similarity }\end{array}$} & \multicolumn{4}{|c|}{ DNA-DNA relatedness values (\%) with strain: } \\
\hline & & & 1 & 2 & 3 & 4 \\
\hline 1. M. coralli sp. nov. $\mathrm{R}-40509^{\mathrm{T}}$ & 58.5 & 100 & 100 & 29 & 30 & 20 \\
\hline 2. M. maritimum LMG $25352^{\mathrm{T}}$ & $57.9 \dagger$ & 97.8 & 42 & 100 & 39 & 24 \\
\hline 3. M. sediminicola $\mathrm{LMG} 25280^{\mathrm{T}}$ & $56.3 \ddagger$ & 98.0 & 28 & 30 & 100 & 15 \\
\hline 4. M. stanieri LMG $6847^{\mathrm{T}}$ & 56.0 & 97.5 & 24 & 26 & 22 & 100 \\
\hline
\end{tabular}

${ }^{\star}$ Similarity values with M. coralli sp. nov. R- $40509^{\mathrm{T}}$.

$\dagger$ Kim et al. (2009b).

$\ddagger$ Huo et al. (2009).

$35 \%$ with $M$. maritimum LMG $25352^{\mathrm{T}}, 29 \%$ with $M$. sediminicola $\mathrm{LMG} 25280^{\mathrm{T}}$ and $22 \%$ with M. stanieri $\mathrm{LMG}$ $6847^{\mathrm{T}}$. It can be concluded that strain R-40509 ${ }^{\mathrm{T}}$ represents a novel species in the genus Marinobacterium (Wayne et al., 1987; Stackebrandt \& Ebers, 2006). The DNA G+C content of strain R-40509 ${ }^{\mathrm{T}}$ was $58.5 \mathrm{~mol} \%$ (Table 1 ).

Table 2. Phenotypic differences between Marinobacterium coralli sp. nov. and its closest phylogenetic neighbours

Strains: 1, M. coralli sp. nov. R-40509 ${ }^{\mathrm{T}} ; 2$, M. maritimum LMG $25352^{\mathrm{T}} ; 3$, M. sediminicola LMG $25280^{\mathrm{T}}$; 4, M. stanieri LMG $6847^{\mathrm{T}}$. Data for reference strains were obtained in this study except where indicated. +, Positive; -, negative; w, weakly positive; ND, not determined.

\begin{tabular}{|c|c|c|c|c|}
\hline Characteristic & 1 & 2 & 3 & 4 \\
\hline \multicolumn{5}{|l|}{ Growth with $\mathrm{NaCl}(\%$, w/v) } \\
\hline 0.5 & + & + & + & - \\
\hline 9 & + & - & - & + \\
\hline 10 & - & - & - & + \\
\hline \multicolumn{5}{|l|}{ Growth at $\left({ }^{\circ} \mathrm{C}\right)$ : } \\
\hline 7 & - & + & - & - \\
\hline 42 & + & - & + & - \\
\hline Esterase lipase (C8) & - & $\mathrm{w}$ & - & + \\
\hline Catalase & - & + & $\mathrm{w}$ & + \\
\hline Acetoin production (Voges-Proskauer) & + & + & $\mathrm{w}$ & $\mathrm{w}$ \\
\hline Tween 80 hydrolysis & $\mathrm{w}$ & - & - & $+^{*}$ \\
\hline \multicolumn{5}{|l|}{ Utilization of: } \\
\hline Acetate & - & - & + & $-{ }^{*}$ \\
\hline DL-Lactic acid & + & $\mathrm{w}$ & $\mathrm{w}$ & $-{ }^{*}$ \\
\hline L-Arabinose & - & $\mathrm{W}$ & $\mathrm{w}$ & $-\dagger$ \\
\hline L-Glutamic acid & + & $\mathrm{w}$ & - & $+\dagger$ \\
\hline L-Proline & + & $\mathrm{w}$ & $\mathrm{w}$ & $+\dagger$ \\
\hline D-Alanine & + & - & - & $-\dagger$ \\
\hline L-Alanine & + & - & - & $+\dagger$ \\
\hline$\beta$-Hydroxybutyric acid & + & - & - & $+\dagger$ \\
\hline Bromosuccinic acid & + & - & - & $\mathrm{ND}$ \\
\hline$\alpha$-Ketovaleric acid & + & - & - & ND \\
\hline \multicolumn{5}{|l|}{ Fatty acid methyl ester composition $\ddagger$} \\
\hline $\mathrm{C}_{10: 0}$ & 3.0 & 4.0 & 3.5 & - \\
\hline $\mathrm{C}_{16: 0}$ & 22.0 & 18.5 & 16.8 & 17.6 \\
\hline $\mathrm{C}_{17: 0}$ cyclo & - & 1.5 & - & - \\
\hline Unknown fatty acid ECL 11.799 & - & - & 1.8 & 1.0 \\
\hline
\end{tabular}

${ }^{\star}$ Kim et al. (2009b).

$\dagger$ Baumann et al. (1983).

$¥$ Fatty acid data are expressed as percentages of the total amount of fatty acids. Only fatty acids that differ between the strains are shown. Fatty acids representing $<1 \%$ are not shown. 
Phenotypic characteristics were determined for the novel isolate and the type strains of the phylogenetically most closely related species of the genus Marinobacterium. The isolate can be differentiated from its closest phylogenetic neighbours by several phenotypic features (Table 2). The isolate grew in medium containing $9 \% \mathrm{NaCl}$ and utilized D-alanine, L-alanine, bromosuccinic acid, $\beta$-hydroxybutyric acid and $\alpha$-ketovaleric acid, but not acetate or L-arabinose. It produced acetoin (Voges-Proskauer), but did not have esterase lipase (C8) or catalase activities. The presence of fatty acids $\mathrm{C}_{10: 0}$ and $\mathrm{C}_{17: 0}$ cyclo and the unknown fatty acid ECL 11.799 can also be used to differentiate the isolate from its closest phylogenetic neighbours (Table 2). The major cellular fatty acids of $\mathrm{R}-40509^{\mathrm{T}}$ were $\mathrm{C}_{18: 1} \omega 7 \mathrm{c}$ $(35 \%)$, summed feature 3 (iso- $\mathrm{C}_{15: 0} \quad 2-\mathrm{OH}$ and/or $\left.\mathrm{C}_{16: 1} \omega 7 c ; 25 \%\right)$ and $\mathrm{C}_{16: 0}(22 \%)$ (Supplementary Table S1 available in IJSEM Online).

Based on the polyphasic analysis presented in this study, it is proposed that strain $\mathrm{R}-40509^{\mathrm{T}}$ represents a novel species, Marinobacterium coralli sp. nov.

\section{Description of Marinobacterium coralli sp. nov.}

Marinobacterium coralli (co.ral'li. L. gen. n. coralli of coral, from which the organism was isolated).

Cells are Gram-negative, moderately halophilic, aerobic, motile, straight rods approximately $1 \mu \mathrm{m}$ wide and $2-5 \mu \mathrm{m}$ long. Catalase-negative and oxidase-positive. Colonies on MA are circular, slightly undulate, convex, smooth, beige translucent in colour and $0.8 \mathrm{~mm}$ in size after 1 day of incubation at $28{ }^{\circ} \mathrm{C}$. Prolific growth occurs between 20 and $40{ }^{\circ} \mathrm{C}$ and at $\mathrm{NaCl}$ concentrations ranging from 1 to $7 \%$ $(\mathrm{w} / \mathrm{v})$. No growth is observed in $0 \% \mathrm{NaCl}$, in $\geqslant 10 \% \mathrm{NaCl}$, at $\leqslant 7{ }^{\circ} \mathrm{C}$ or at $\geqslant 43{ }^{\circ} \mathrm{C}$. Shows alkaline phosphatase, esterase (C4), leucine arylamidase, acid phosphatase and naphthol-AS-BI-phosphohydrolase activities and produces acetoin (Voges-Proskauer). Capable of assimilating methyl pyruvate, monomethylsuccinate, cis-aconitic acid, $\alpha$-hydroxybutyric acid, $\beta$-hydroxybutyric acid, $\gamma$-hydroxybutyric acid, $p$-hydroxyphenylacetic acid, $\alpha$-ketobutyric acid, $\alpha$-ketoglutaric acid, $\alpha$-ketovaleric acid, DL-lactic acid, succinic acid, bromosuccinic acid, succinamic acid, D-alanine, L-alanine, L-alanylglycine, L-glutamic acid, L-proline and phenylethylamine. Weak reactions were observed for hydrolysis of Tween 40 and Tween 80 and for assimilation of $N$ acetyl-D-glucosamine, citric acid, alaninamide, L-asparagine and L-phenylalanine. Negative for: esterase lipase (C8), lipase $(\mathrm{C} 14)$, valine arylamidase, cystine arylamidase, trypsin, $\alpha$-chymotrypsin, $\alpha$-galactosidase, $\beta$-galactosidase, $\beta$-glucuronidase, $\alpha$-glucosidase, $\beta$-glucosidase, $N$-acetyl- $\beta$-glucosaminidase, $\alpha$-mannosidase, $\alpha$-fucosidase, arginine dihydrolase, lysine decarboxylase, ornithine decarboxylase, urease, gelatinase and tryptophan deaminase activities; $\mathrm{H}_{2} \mathrm{~S}$ and indole production; reduction of nitrate and nitrite to $\mathrm{N}_{2}$ gas; fermentation of glucose, mannitol, inositol, sorbitol, rhamnose, sucrose, melibiose, amygdalin and arabinose; and assimilation of citrate, $\alpha$-cyclodextrin, dextrin, glycogen,
$\mathrm{N}$-acetyl-D-galactosamine, adonitol, L-arabinose, D-arabitol, cellobiose, i-erythritol, D-fructose, L-fucose, D-galactose, gentiobiose, $\alpha$-D-glucose, myo-inositol, $\alpha$-lactose, lactulose, maltose, D-mannitol, D-mannose, melibiose, methyl $\beta$-Dglucoside, psicose, raffinose, L-rhamnose, D-sorbitol, sucrose, trehalose, turanose, xylitol, acetic acid, formic acid, D-galactonic acid lactone, D-galacturonic acid, D-gluconic acid, D-glucosaminic acid, D-glucuronic acid, itaconic acid, malonic acid, propionic acid, quinic acid, D-saccharic acid, sebacic acid, glucuronamide, L-aspartic acid, glycyl L-aspartic acid, glycyl L-glutamic acid, L-histidine, L-hydroxyproline, L-leucine, L-ornithine, L-pyroglutamic acid, D-serine, L-serine, L-threonine, DL-carnitine, $\gamma$-aminobutyric acid, urocanic acid, inosine, uridine, thymidine, putrescine, 2-aminoethanol, 2,3-butanediol, glycerol, DL- $\alpha$-glycerol phosphate, glucose 1-phosphate, glucose 6-phosphate, potassium gluconate, capric acid, adipic acid, malate and trisodium citrate. The main cellular fatty acids are $\mathrm{C}_{18: 1} \omega 7 \mathrm{c}$, summed feature 3 (iso$\mathrm{C}_{15: 0} 2-\mathrm{OH}$ and/or $\mathrm{C}_{16: 1} \omega 7 c$ ) and $\mathrm{C}_{16: 0}$. The following fatty acids are present in small amounts: $\mathrm{C}_{10: 0} 3-\mathrm{OH}, \mathrm{C}_{12: 0}$ and $\mathrm{C}_{10: 0}$ (Supplementary Table S1 available in IJSEM Online).

The type strain is $\mathrm{R}-40509^{\mathrm{T}}$ (=LMG $25435^{\mathrm{T}}=\mathrm{CAIM}$ $1449^{\mathrm{T}}$ ), isolated from mucus of the endemic coral Mussismilia hispida located in the São Sebastião channel, SP, Brazil. The DNA G $+\mathrm{C}$ content of the type strain is $58.5 \mathrm{~mol} \%$. The phenotypic profile of $M$. coralli is at present based on one strain. As more strains of this species are isolated and tested, the profile may change slightly.

\section{Acknowledgements}

The authors acknowledge grants from FAPERJ, FAPESP, CNPq and IFS. L. A. C. acknowledges a PhD scholarship provided by CNPq. The BCCM/LMG Bacteria Collection is supported by the Federal Public Planning Service-Science Policy, Belgium. We thank Katrien Engelbeen (BCCM/LMG), Stefanie Van Trappen (BCCM/LMG), Alvaro Migotto (CEBIMAR-USP), Bruno Gomez-Gil and Cristiane C. Thompson for their technical assistance and valuable comments.

\section{References}

Baumann, P., Bowditch, R. D., Baumann, L. \& Beaman, B. (1983). Taxonomy of marine Pseudomonas species: P. stanieri sp. nov.; $P$. perfectomarina sp. nov., nom. rev.; $P$. nautica; and $P$. doudoroffii. Int $J$ Syst Bacteriol 33, 857-865.

Bowditch, R. D., Baumann, L. \& Baumann, P. (1984). Description of Oceanospirillum kriegii sp. nov. and O. jannaschii sp. nov. and assignment of two species of Alteromonas to this genus as O. commune comb. nov. and O. vagum comb. nov. Curr Microbiol 10, 221230.

Brown, B. E. \& Bythell, J. C. (2005). Perspectives on mucus secretion in reef corals. Mar Ecol Prog Ser 296, 291-309.

Chang, H.-W., Nam, Y.-D., Kwon, H.-Y., Park, J. R., Lee, J.-S., Yoon, J.-H., An, K.-G. \& Bae, J.-W. (2007). Marinobacterium halophilum sp. nov., a marine bacterium isolated from the Yellow Sea. Int J Syst Evol Microbiol 57, 77-80.

Chenna, R., Sugawara, H., Koike, T., Lopez, R., Gibson, T. J., Higgins, D. G. \& Thompson, J. D. (2003). Multiple sequence alignment with the CLUSTAL series of programs. Nucleic Acids Res 31, 3497-3500. 
Chimetto, L. A., Brocchi, M., Thompson, C. C., Martins, R. C. R., Ramos, H. B. \& Thompson, F. L. (2008). Vibrios dominate as culturable nitrogen-fixing bacteria of Brazilian coral Mussismilia hispida. Syst Appl Microbiol 31, 312-319.

Chimetto, L. A., Brocchi, M., Gondo, M., Thompson, C. C., GomezGil, B. \& Thompson, F. L. (2009). Genomic diversity of vibrios associated with the Brazilian coral Mussismilia hispida and its sympatric zoanthids (Palythoa caribaeorum, Palythoa variabilis and Zoanthus solanderi). J Appl Microbiol 106, 1818-1826.

Ducklow, H. W. \& Mitchell, R. (1979). Composition of mucus released by coral reef coelenterates. Limnol Oceanogr 24, 706-714.

Eck, R. V. \& Dayhoff, M. O. (1966). Atlas of Protein Sequence and Structure. Silver Springs, MD: National Biomedical Research Foundation.

Ezaki, T., Hashimoto, Y. \& Yabuuchi, E. (1989). Fluorometric deoxyribonucleic acid-deoxyribonucleic acid hybridization in microdilution wells as an alternative to membrane filter hybridization in which radioisotopes are used to determine genetic relatedness among bacterial strains. Int J Syst Bacteriol 39, 224-229.

Felsenstein, J. (1985). Confidence limits on phylogenies: an approach using the bootstrap. Evolution 39, 783-791.

González, J. M., Mayer, F., Moran, M. A., Hodson, R. E. \& Whitman, W. B. (1997). Microbulbifer hydrolyticus gen. nov., sp. nov., and Marinobacterium georgiense gen. nov., sp. nov., two marine bacteria from a lignin-rich pulp mill waste enrichment community. Int J Syst Bacteriol 47, 369-376.

Goris, J., Suzuki, K., De Vos, P., Nakase, T. \& Kersters, K. (1998). Evaluation of a microplate DNA-DNA hybridization method compared with the initial renaturation method. Can J Microbiol 44, $1148-1153$.

Huo, Y.-Y., Xu, X.-W., Cao, Y., Wang, C.-S., Zhu, X.-F., Oren, A. \& $\mathrm{Wu}$, M. (2009). Marinobacterium nitratireducens sp. nov. and Marinobacterium sediminicola sp. nov., isolated from marine sediment. Int J Syst Evol Microbiol 59, 1173-1178.

Huys, G., Vancanneyt, M., Coopman, R., Janssen, P., Falsen, E., Altwegg, M. \& Kersters, K. (1994). Cellular fatty acid composition as a chemotaxonomic marker for the differentiation of phenospecies and hybridization groups in the genus Aeromonas. Int J Syst Bacteriol 44, 651-658.

Kim, H., Choo, Y.-J., Song, J., Lee, J.-S., Lee, K. C. \& Cho, J.-C. (2007). Marinobacterium litorale sp. nov. in the order Oceanospirillales. Int $\mathrm{J}$ Syst Evol Microbiol 57, 1659-1662.

Kim, Y.-G., Jin, Y.-A., Hwang, C. Y. \& Cho, B. C. (2008). Marinobacterium rhizophilum sp. nov., isolated from the rhizosphere of the coastal tidal-flat plant Suaeda japonica. Int J Syst Evol Microbiol 58, 164-167.

Kim, H., Oh, H.-M., Yang, S.-J., Lee, J.-S., Hong, J.-S. \& Cho, J.-C. (2009a). Marinobacterium marisflavi sp. nov., isolated from a costal seawater. Curr Microbiol 58, 511-515.

Kim, S.-J., Park, S.-J., Yoon, D.-N., Park, B.-J., Choi, B.-R., Lee, D.-H., Roh, Y. \& Rhee, S.-K. (2009b). Marinobacterium maritimum sp. nov., a marine bacterium isolated from Arctic sediment. Int J Syst Evol Microbiol 59, 3030-3034.

Kim, J. M., Lee, S. H., Jung, J. Y. \& Jeon, C. O. (2010). Marinobacterium lutimaris sp. nov., isolated from a tidal flat. Int $J$ Syst Evol Microbiol 60, 1828-1831.
Kimura, M. (1980). A simple method for estimating evolutionary rates of base substitutions through comparative studies of nucleotide sequences. J Mol Evol 16, 111-120.

Kovacs, N. (1956). Identification of Pseudomonas pyocyanea by the oxidase reaction. Nature 178, 703.

Mesbah, M., Premachandran, U. \& Whitman, W. B. (1989). Precise measurement of the $\mathrm{G}+\mathrm{C}$ content of deoxyribonucleic acid by high-performance liquid chromatography. Int J Syst Bacteriol 39, 159167.

Reshef, L., Koren, O., Loya, Y., Zilber-Rosenberg, I. \& Rosenberg, E. (2006). The coral probiotic hypothesis. Environ Microbiol 8, 20682073.

Ritchie, K. B. (2006). Regulation of microbial populations by coral surface mucus and mucus-associated bacteria. Mar Ecol Prog Ser 322, $1-14$.

Rosenberg, E., Koren, O., Reshef, L., Efrony, R. \& Zilber-Rosenberg, I. (2007). The role of microorganisms in coral health, disease and evolution. Nat Rev Microbiol 5, 355-362.

Rzhetsky, A. \& Nei, M. (1992). A simple method for estimating and testing minimum evolution trees. Mol Biol Evol 9, 945-967.

Saitou, N. \& Nei, M. (1987). The neighbor-joining method: a new method for reconstructing phylogenetic trees. Mol Biol Evol 4, 406425.

Satomi, M., Kimura, B., Hamada, T., Harayama, S. \& Fujii, T. (2002). Phylogenetic study of the genus Oceanospirillum based on 16S rRNA and gyrB genes: emended description of the genus Oceanospirillum, description of Pseudospirillum gen. nov., Oceanobacter gen. nov. and Terasakiella gen. nov. and transfer of Oceanospirillum jannaschii and Pseudomonas stanieri to Marinobacterium as Marinobacterium jannaschii comb. nov. and Marinobacterium stanieri comb. nov. Int J Syst Evol Microbiol 52, 739-747.

Shnit-Orland, M. \& Kushmaro, A. (2009). Coral mucus-associated bacteria: a possible first line of defense. FEMS Microbiol Ecol 67, 371380.

Stackebrandt, E. \& Ebers, J. (2006). Taxonomic parameters revisited: tarnished gold standards. Microbiol Today 33, 152-155.

Tamura, K., Dudley, J., Nei, M. \& Kumar, S. (2007). MEGA4: molecular evolutionary genetics analysis (MEGA) software version 4.0. Mol Biol Evol 24, 1596-1599.

Thompson, F. L., Hoste, B., Vandemeulebroecke, K. \& Swings, J. (2001). Genomic diversity amongst Vibrio isolates from different sources determined by fluorescent amplifed fragment length polymorphism. Syst Appl Microbiol 24, 520-538.

Wayne, L. G., Brenner, D. J., Colwell, R. R., Grimont, P. A. D., Kandler, O., Krichevsky, M. I., Moore, L. H., Moore, W. E. C., Murray, R. G. E. \& other authors (1987). International Committee on Systematic Bacteriology. Report of the ad hoc committee on reconciliation of approaches to bacterial systematics. Int J Syst Bacteriol 37, 463-464.

Wild, C., Rasheed, M., Werner, U., Franke, U., Johnstone, R. \& Huettel, M. (2004). Degradation and mineralization of coral mucus in reef environments. Mar Ecol Prog Ser 267, 159-171.

Willems, A., Doignon-Bourcier, F., Goris, J., Coopman, R., de Lajudie, P., De Vos, P. \& Gillis, M. (2001). DNA-DNA hybridization study of Bradyrhizobium strains. Int J Syst Evol Microbiol 51, 13151322 . 